\title{
Analiza administrativnih bremen okoljskih predpisov v Sloveniji
}

\author{
UDK: $502.14: 35.073$ \\ Maja Klun, Luka Petkovšek \\ Univerza v Ljubljani, Fakulteta za upravo \\ maja.klun@fu.uni-lj.si; luka.petkovsek@fu.uni-lj.si
}

\begin{abstract}
IZVLEČEK
Pomembno vprašanje ob uvedbi predpisov, ki zadevajo tudi gospodarstvo, je, kakšna je povezanost med uvedbo regulative in konkurenčnostjo podjetij in države ter ali predpisi povzročajo preveliko administrativno breme in s tem previsoke administrativne stroške. $V$ članku je opravljena analiza okoljske regulative, ki kaže na potencialne povzročitelje previsokih administrativnih bremen na tem področju. Analiza je privedla do podobnih ugotovitev kot so bile ugotovljene v Nizozemski in Veliki Britaniji. Obstoječa okoljska regulativa namreč povzroča preveč podvajanj informacij različnim ali celo istim institucijam v državi. Prav tako je pogostost obračunskih obdobij pri nekaterih okoljskih dajatvah neekonomična.
\end{abstract}

Ključne besede: administrativni stroški, administrativno breme, okoljski predpisi

\section{Uvod}

Pomembno vprašanje, ki se zastavlja pri uvedbi predpisov, ki zadevajo tudi gospodarstvo, je, kakšna je povezanost med uvedbo regulative in konkurenčnostjo podjetij in države. Enako velja tudi za okoljske predpise. Ugotovitve, ki izhajajo iz ekonomske teorije, si med seboj močno nasprotujejo. Iz konvencionalne ekonomske teorije sledi, da zahteve okoljske regulacije neizogibno povečujejo privatne stroške gospodarstva, zato prihaja do zmanjšanja konkurenčnosti države. Temu nasprotne teorije so ekonomske teorije, ki zahteve okoljske regulacije povezujejo s pritiskom na inovacije, z ustvarjanjem tehnične ali tržne prednosti in s posledičnim povečanjem produktivnosti podjetij na kratki in srednji rok, zaradi česar konkurenčnost države ni ogrožena ali pa se lahko celo izboljša (Filiplič, 2004, str. 12).

Administrativni stroški, povezani z izpolnjevanjem okoljskih predpisov, postanejo problematični šele takrat, kadar je delež administrativnih bremen $\vee$ 
Maja Klun, Luka Petkovšek

Analiza administrativnih bremen okoljskih predpisov v Sloveniji

teh stroških velik. Z administrativnimi stroški se pojmuje vse stroške, ki jih imajo podjetja z izpolnjevanjem zahtev iz različnih predpisov - za poročila, dokumentacijo, napovedi, itd. Del teh stroškov povzročajo zahteve po informacijah, ki jih podjetja ne bi pripravljala, v kolikor ne bi bilo zahtev različnih predpisov. Ta del stroškov imenujemo administrativno breme (SCM Network, 2007).

$\checkmark$ članku so predstavljeni osnovni okoljski predpisi ter finančni instrumenti, ki so del okoljske regulative. Sledi analiza odpravljanja administrativnih bremen $\checkmark$ Nizozemski in Veliki Britaniji ter analiza postopkov in nastajanje administrativnih bremen na področju okoljske regulative $\vee$ Sloveniji. Na koncu so podani nekateri poenostavljeni predlogi znižanja administrativnih stroškov in bremen za podjetja, ki ne bi zahtevali bistvenih sprememb zakonodaje.

\section{Okoljska regulativa v Sloveniji}

\subsection{Osnovni predpisi z okoljskega področja v Sloveniji}

Primarni zakon s področja varovanja okolja je Zakon o varstvu okolja (Ur. list RS, št. 41/2004, 20/2006), kjer so določena temeljna načela varstva okolja, ukrepi varstva okolja, spremljanje stanja okolja in informacije o okolju, ekonomski in finančni instrumenti varstva okolja, javne službe varstva okolja in druga, z varstvom okolja povezana vprašanja. Namen varstva okolja je spodbujanje in usmerjanje takšnega družbenega razvoja, ki omogoča dolgoročne pogoje za človekovo zdravje, počutje in kakovost njegovega življenja ter ohranjanje biotske raznovrstnosti. Prvi zakon s področja varovanja okolja je bil sprejet že leta 1993, leta 2004 pa je zakon doživel prenovo in uskladitev s smernicami in direktivami Evropske unije in drugih mednarodnih organizacij. Cilji varstva okolja so naslednji (ZVO-1, 2. člen):

- preprečitev in zmanjšanje obremenjevanja okolja;

- ohranjanje in izboljševanje kakovosti okolja;

- trajnostna raba naravnih virov;

- zmanjšanje rabe energije in večja uporaba obnovljivih virov energije;

- odpravljanje posledic obremenjevanja okolja, izboljšanje porušenega naravnega ravnovesja in ponovno vzpostavljanje njegovih regeneracijskih sposobnosti;

- povečanje snovne učinkovitosti proizvodnje in potrošnje;

- opuščanje in nadomeščanje uporabe nevarnih snovi. 


\section{Analiza administrativnih bremen okoljskih predpisov v Sloveniji}

Večina predpisov Evropske unije s področja okolja je zasnovana na podlagi direktiv, ki jih morajo posamezne države članice vnesti v svoj pravni red.

Evropska unija se je obvezala, da promovira varstvo okolja na mednarodni ravni, saj tudi naravno okolje ne pozna meja. Še naprej bo imela ključno vlogo pri pospeševanju multinacionalnih in multilateralnih sporazumov (na tem mestu velja izpostaviti Kjotski sporazum) in iskanju novih finančnih sredstev za pospešitev uvajanja vseh ključnih okoljskih sporazumov, kot tudi varstva okolja v državah v razvoju, tako da se poveča globalni okoljski nadzor (Mešl, 2004, str. 40).

Kjotski sporazum je mednarodni sporazum, s katerim naj bi zmanjšali emisije ogljikovega dioksida in petih drugih toplogrednih plinov. Sprejelo ga je 141 držav sveta, med njimi tudi Slovenija, z namenom, da bi zaustavili segrevanje ozračja. Protokol je začel, z rusko ratifikacijo, veljati 16. februarja 2005. Emisije držav, ki so sporazum ratificirale, pomenijo $61 \%$ svetovnih emisij. V prvem ciljnem obdobju 2008-2012 bodo države, ki so protokol ratificirale, skušale emisije zmanjšati za najmanj pet odstotkov v primerjavi z letom 1990. Če ta cilj primerjamo s količino emisij, ki bi jih pričakovali za leto 2010 brez uresničevanja ciljev protokola, to pomeni pravzaprav 29 odstotno znižanje. Evropska unija proizvaja okoli $21 \%$ vseh emisij toplogrednih plinov. Zavezala se je, da jih bo v povprečju zmanjšala za osem odstotkov glede na leto 1990.

Temeljna direktiva na področju preprečevanja industrijskega onesnaževanja je direktiva o celovitem preprečevanju industrijskega onesnaževanja in nadzoru nad njim (IPPC - Integrated Pollution Protection and Control), katere namen je celovito preprečevati in nadzorovati onesnaženost ter dosegati visoko stopnjo varovanja okolja kot celote. Direktiva določa načela, ki jih je treba upoštevati pri enotnem obratovalnem dovoljenju velikih industrijskih podjetij. Direktiva je bila vnesena tudi $\vee$ slovenski pravni red in sicer $v$ Zakon o varstvu okolja.

Horizontalne direktive so tiste, ki veljajo za več industrijskih sektorjev in niso omejene na posamezen segment varstva okolja. $\vee$ osnovi jih delimo na tiste, ki urejajo vprašanja proizvodnje oziroma emisij iz tehnoloških postopkov, in tiste, ki urejajo vprašanja kakovosti proizvodov. $V$ prvo skupino sodijo vse direktive, ki imajo $v$ svojih dodatkih spisek industrijskih aktivnosti, za katere veljajo in za katere je treba za obratovanje pridobiti dovoljenje pristojnega telesa, $v$ drugo pa tiste, ki omogočajo, da se izdelki sploh prodajajo ali pa dajejo pravico do opremljanja izdelkov s posebno oznako, ki jih ločuje od drugih izdelkov na podlagi lastnosti, ki jih izkazujejo $v$ okoljskem smislu pri njihovi izdelavi, uporabi in odstranjevanju (ARSO, 2007). 
Maja Klun, Luka Petkovšek

\section{Analiza administrativnih bremen okoljskih predpisov v Sloveniji}

Direktive, ki urejajo vprašanja proizvodnje oziroma emisij iz tehnoloških postopkov, so (ARSO, 2007):

- direktiva o presoji vplivov na okolje (EIA);

- direktiva o celovitem preprečevanju industrijskega onesnaževanja in nadzoru nad njim (IPPC);

- direktiva o zmanjševanju emisije lahko hlapnih organskih snovi pri uporabi topil (VOC);

- direktiva o nadzoru nad nevarnostmi velikih nesreč (SEVESO);

- uredba o prostovoljni udeležbi podjetij $\vee$ sistemu okoljskega upravljanja (EMAS).

\subsection{Ekonomski in finančni instrumenti}

Ekonomski in finančni instrumenti, s katerimi država pospešuje in spodbuja doseganje ciljev varstva okolja, so naslednji (ZVO-1, 111. člen):

- okoljske dajatve;

- zavarovanja, bančne garancije in druge oblike finančnega jamstva;

- krediti z ugodnejšo obrestno mero za naložbe, ki prispevajo k varstvu okolja;

- kavcije in druge oblike varščin;

- trgovanje s pravicami do emisij;

- skupne naložbe v projekte zmanjševanja obremenjevanja okolja;

- sredstva proračuna.

Trenutno je najbolj aktualno trgovanje s pravicami do emisije toplogrednih plinov (gre za t.i. emisijske kupone). Sistem trgovanja z emisijami je v Evropski uniji pričel delovati z letom 2005. Gre za enega izmed prožnih mehanizmov, ki jih je uvedel Kjotski protokol. Namen trgovanja je, da se emisije toplogrednih plinov zmanjšujejo tam, kjer je to najbolj poceni. Slovenija je z vstopom v Evropsko unijo dobila tudi obvezno sodelovanje v evropski trgovalni shemi. Prvi emisijski kuponi so bili podeljeni, Evropska komisija pa je sprejela tudi že drugi državni načrt razdelitve emisijskih kuponov za obdobje 2008-2012. Skupno število emisijskih kuponov, ki so bili podeljeni v Republiki Sloveniji v trgovalnem obdobju 2005-2007, znaša 26.275.969 ton $\mathrm{CO}_{2}$ (1 kupon = 1 tona) in vključuje 94 naprav. Naprave, ki so $v$ prvem trgovalnem obdobju dobile največ kuponov, so večinoma $v$ termoelektrarnah, saj je bilo zanje razdeljenih dobrih $68 \%$ kuponov (Focus, 2007). 


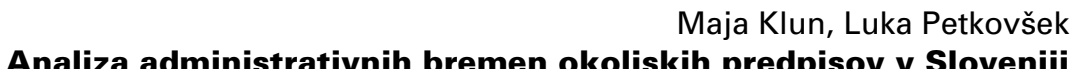

$\checkmark$ Sloveniji trenutno poznamo osem okoljskih dajatev, in sicer (CURS, 2007 in Klun, 2006, str. 79):

- dajatev za onesnaževanje zraka z emisijo ogljikovega dioksida;

- dajatev za onesnaževanje okolja zaradi uporabe mazalnih olj in tekočin;

- dajatev za onesnaževanje okolja zaradi nastajanja izrabljenih motornih vozil;

- dajatev za onesnaževanje okolja zaradi odlaganja odpadkov;

- dajatev za onesnaževanje okolja zaradi odvajanja odpadnih voda;

- dajatev za onesnaževanje okolja zaradi nastajanja izrabljenih gum;

- dajatev za onesnaževanje okolja zaradi nastajanja odpadne embalaže;

- dajatev za onesnaževanje okolja zaradi nastajanja odpadne električne in elektronske opreme.

Največ prilivov $v$ državni proračun se steče od dajatve za onesnaževanje zraka z emisijo ogljikovega dioksida, saj ta dajatev obdavčuje največje onesnaževalce. Najmanj prilivov pa je od treh na novo uvedenih okoljskih dajatev, ki so bile uvedene $v$ letu 2006. Delež okoljskih dajatev $v$ državnem proračunu je relativno majhen, saj je $v$ letu 2006 znašal zgolj 0,7\% celotnih prihodkov, leta 2005 pa $0,9 \%$ (MF, 2007). Po podatkih Agencije RS za okolje so tako $v$ letu 2005 od okoljskih dajatev za komunalne vode od dobrih 9,6 milijarde tolarjev za naložbe za to področje namenili kar 9,3 milijarde tolarjev. Podobno velja tudi pri komunalnih odlagališčih, kjer so od slabih 2,9 milijarde tolarjev za namenske naložbe namenili prek 2,5 milijarde tolarjev (Marcon, 2006, str. 2-3).

\subsection{Okoljski predpisi in administrativni stroški}

Ker se podjetja osredotočajo predvsem na porabljeni čas in stroške postopkov pri zakonodajalcu, hkrati pa so nagnjena $\mathrm{k}$ podcenjevanju koristi predpisov za gospodarstvo in širšo družbo, nastaja mnenje, da okoljski predpisi povzročajo obremenitve gospodarstva, neučinkovitost in manjšo konkurenčnost (Praška izjava, 2005, str. 1). Druga slabost, ki se izkazuje $\vee$ praksi, je, da okoljska regulacija po mnenju nekaterih ekonomistov poleg povečanih produkcijskih stroškov povzroči selitev umazane industrije $v$ države $z$ manjšimi okoljskimi zahtevami. Poleg tega se pričakuje, da se bodo države znašle $v$ medsebojni tekmi zniževanja okoljskih standardov, z namenom privabljanja tujih investicij, ki bi vplivale na povečanje domače gospodarske rasti, konkurenčnosti in posledično blaginje prebivalstva. 


\section{Maja Klun, Luka Petkovšek}

\section{Analiza administrativnih bremen okoljskih predpisov v Sloveniji}

Vendar pa je treba poudariti, da ugotovitve kažejo, da okoljska regulacija ne vpliva negativno na konkurenčnost podjetij in države v primeru, ko so sprejeti ustrezni okoljski ukrepi z vidika spodbujanja produktivnosti podjetij ter se jih izvaja učinkovito (Filiplič, 2004, str. 14-15). Tudi primeri posameznih podjetij dokazujejo, da taki prihranki niso nujno kratkoročni. Farmacevtsko podjetje Baxter International je izračunalo, da prihrani letno več kot 50 milijonov EUR $\mathrm{s}$ pomočjo ukrepov, kot so zmanjšanje embalaže in odpadkov, ki jih vpeljujejo od leta 1996. Tehnološko podjetje 3M je zastavilo svoj program preprečevanja onesnaževanja leta 1975 in je še vedno deležno njegovih koristi, pri čemer so v tem času prihranili prek 740 milijonov EUR. Dobri predpisi imajo tako pozitiven učinek prek spodbujanja dinamičnih odgovorov, inovacij in boljših praks. Svetovna banka je opazila, da "v nasprotju s splošno percepcijo, višji ekološki standardi v industrijskih državah niso prispevali k zmanjšanju njihove mednarodne konkurenčnosti". Svetovni inštitut za naravne vire pravi: "Ni nobenega dokaza, da panoge, ki jih prizadenejo stroški predpisov, dosegajo slabše rezultate na mednarodnih trgih".

Torej sodoben pristop uvajanja okoljskih predpisov lahko (Praška izjava, 2005, str. 1-9):

- zniža stroške industrije in gospodarstva;

- ustvari trge za okoljske izdelke in storitve;

- pospeši inovativnost;

- zmanjša poslovna tveganja in poveča zaupanja finančnih trgov in zavarovateljev;

- podpre konkurenčne prednosti in oblikuje konkurenčne trge;

- ustvarja in ohranja delovna mesta;

- izboljša zdravje delovne sile in širše družbe;

- zaščiti naravne vire, od katerih je odvisno tako gospodarstvo, kot mi vsi.

Slabosti se kažejo predvsem $\vee$ povečevanju dodatnih administrativnih bremen podjetij in $\mathrm{s}$ tem $v$ povečevanju stroškov poslovanja. Iz tega tudi sledi načelo onesnaževalec plača (ang. Polluter Pays Principle - PPP). To načelo je zajeto tudi $\vee$ Zakonu o varstvu okolja $\vee$ 10. členu (načelo plačila za obremenjevanje), kjer je določeno, da povzročitelj obremenitve krije vse stroške predpisanih ukrepov za preprečevanje in zmanjševanje onesnaževanja ter tveganja za okolje, rabo okolja ter odpravo posledic obremenjevanja okolja. Pri tem proizvajalci del stroškov prenesejo na potrošnika, končnega kupca, tako da ti stroški dvigujejo tudi cene proizvodov in storitev. Prenos okoljskih stroškov (ki vsebujejo tudi administrativne) na potrošnika je $\vee$ veliki meri upravičen. Okoljske 
škode $\vee$ obliki emisij, odpadkov, črpanja naravnih virov ne povzroča le proizvodnja, temveč tudi potrošnja. Ta vidik se $v$ današnji družbi žal precej ignorira. Zelo pomembno je, da potrošnik bodisi kot neposredni bodisi kot posredni onesnaževalec, odgovarja za svojo izbiro, obnašanje. Samo sočasna sprememba vzorcev proizvodnje in vzorcev potrošnje prinaša trajne spremembe kakovosti okolja. Odprto pa ostaja vprašanje, v kolikšni meri je upravičeno prenesti stroške na potrošnika.

Slovenija je z vstopom v Evropsko unijo začela pospešeno delovati tudi na področju učinkovitosti javne uprave. Tako je začela vnašati določena načela, ki so nekoč veljala samo $v$ gospodarstvu tudi $v$ državno, javno upravo. $S$ tem področjem se v največji meri ukvarja Ministrstvo za javno upravo. Pomemben korak naprej pri ustvarjanju prijazne in učinkovite javne uprave ter pri odpravljanju administrativnih ovir je Program ukrepov za odpravo administrativnih ovir, ki ga je sprejela vlada konec leta 2005 na predlog Ministrstva za javno upravo. Namen tega programa je doseči cilj učinkovite javne uprave za državljane in gospodarstvo in uvesti boljše reguliranje na področju predpisov in sprejemanja odločitev. Razvoj dobrega reguliranja $\vee$ javni upravi je ključen dejavnik povečanja konkurenčnosti in osrednja razvojna prioriteta Slovenije, ki stremi k učinkoviti in cenejši državi. Boljše reguliranje predstavlja ključni dejavnik povečanja gospodarske rasti in učinkovitosti poslovnega okolja. Vsi nosilci ukrepov bodo program upoštevali pri pripravi normativnih in drugih programov dela za obdobje 2006-2008, Ministrstvo za javno upravo pa je pristojno za usklajevanje in nadzor nad izvajanjem programa. Gradivo vsebuje 34 ukrepov, potrebnih za uresničitev posameznih ciljev odprave administrativnih ovir. Naj omenimo, da med njimi ni ukrepov s področja okoljskih predpisov.

\section{Zmanjševanje administrativnih stroškov in bremen s področja okoljskih predpisov v Nizozemski in Veliki Britaniji}

Nizozemska je poenostavila sistem pridobivanja dovoljenj s področja okolja in sicer z zamenjavo posameznih dovoljenj na skupno dovoljenje, ki obravnava več področij. Enako velja tudi za sporočanje oziroma obračunavanje različnih okoljskih dajatev. Poenostavitev so napravili tudi na področju registra okoljskih zavezancev. Ta register je povezan tudi z drugimi registri, kot je na primer register prebivalstva, socialno varstveni register, itd. Razvoj, ki ga je napravila nizozemska vlada, je šel v smeri enotnega registra za več področij, kar omogoča večji nadzor in še nekatere druge prednosti. Pomemben korak pa so Nizozemci 
Maja Klun, Luka Petkovšek

\section{Analiza administrativnih bremen okoljskih predpisov v Sloveniji}

naredili tudi z zamenjavo specifičnih zakonov in pravilnikov s področja okolja z univerzalnimi predpisi, kar pomeni, da ni več treba pridobivati nekaterih specifičnih dovoljenj za opravljanje dejavnosti. Če bo zadeva uspešna na vseh področjih industrije, se bodo administrativni stroški zmanjšali za dobrih 90 milijonov evrov v primerjavi z letom 1995 (OECD, 2003, str. 174-193).

Za okolje $\vee$ Veliki Britaniji skrbi ministrstvo za hrano, okolje in kmetijstvo, imenovano DEFRA (Department for Food Environment and Rural Affairs). DEFRA je $v$ sodelovanju z Velško vlado in okoljsko agencijo (NetRegs) pripravila že številne raziskave in analize na področju okolja. S tega področja obstaja veliko narejenih študij. Pomembno je omeniti dve študiji, in sicer (Defra, 2006a in NetRegs, 2005):

- Študija, ki jo je pripravila okoljska agencija Netregs iz leta 2005 (SMEEnvironment 2005: UK) - gre za raziskavo okoljske osveščenosti in okoljskih praks $v$ podjetjih $\vee$ Veliki Britaniji, predvsem pomoč malim podjetjem pri uveljavljanju okoljske regulative;

- Študija, ki jo je pripravila DEFRA (Environmental Permitting Programme iz leta 2006). DEFRA je pripravila raziskavo oziroma pobudo za združenje dveh velikih okoljskih sistemov (IPPC- Integrirano preprečevanje in nadzor nad onesnaževanjem okolja in Sistema dovoljenj na področju ravnanja z odpadki) z namenom poenotenja sistema dovoljenj. Ocenili so, da bi enotno oblikovan sistem dovoljenj (okoljski program dovoljenj) prinesel administrativne prihranke $v$ višini okrog 70 milijonov angleških funtov $v$ 10 letih za gospodarstvo in javni sektor, s potencialom dodatnih ekonomskih koristi in to brez ogrožanja okoljskih standardov. Oba sistema imata namreč skupne točke: številna podjetja potrebujejo obe vrsti dovoljenj, nekatere oblike ravnanj z odpadki spadajo $v$ en sistem, druge $v$ drugega. Predlagani enotni sistem bi vseboval enostavne in jasne smernice za zavezance. Tako bi se gospodarstvo in javni sektor lahko bolj osredotočala na okoljske rezultate in manj na način, kako jih doseči. Predlog konkretno vsebuje spremembe $v$ formularjih za prijavljanje, spremembe $\checkmark$ variacijah, prenosu in odpovedi dovoljenj, spremembe $v$ postopkih dokazovanja sposobnosti upravljavca. Predlog je oblikovan tako, da omogoča $v$ prihodnosti razširitev na druge okoljske sisteme.

Na področju okolja naj bi z ukrepi privarčevali do leta 2010 okrog 160 milijonov funtov, od tega s poenostavitvijo okoljske zakonodaje 25 milijonov funtov. Poenostavili so tudi področje pridobivanja okoljskih dovoljenj oziroma pridobivanje dovoljenj povezanih z okoljem. Do leta 2010 bodo tako privarčevali za 8,9 milijonov funtov. Uvedli so t.i. enotno standardno dovoljenje za več področij 


\section{Maja Klun, Luka Petkovšek Analiza administrativnih bremen okoljskih predpisov v Sloveniji}

(podjetja izpolnijo en sam obrazec za več področij pridobivanja dovoljenj). Sistem so tudi poenostavili z uvedbo elektronske oddaje prijave dejavnosti oziroma pridobitev dovoljenja (Defra, 2006b, str.16-25 in str. 40).

\section{Analiza administrativnih bremen okoljskih predpisov v Sloveniji}

\subsection{Pridobivanje okoljskih dovoljenj}

Upravljavci, ki opravljajo dejavnost oziroma imajo v lasti napravo, ki lahko povzroča onesnaževanje okolja večjega obsega, morajo pridobiti okoljevarstveno dovoljenje. Področje pridobitve okoljevarstvenega dovoljenja natančneje ureja Uredba o vrsti dejavnosti in naprav, ki lahko povzročajo onesnaževanje okolja večjega obsega (Ur. list RS, št. 97/2004). Uredba je bila sprejeta na podlagi direktive 96/61/EC (t.i. IPPC direktiva), kjer je Evropska komisija določila osnovne standarde in pravila na področju celovitega preprečevanja in nadzorovanja industrijskega onesnaževanja in Zakona o varstvu okolja. Za zbiranje prijav in vlog, je pristojna Agencija RS za okolje, kot organ v sestavi Ministrstva za okolje in prostor.

Pridobitev okoljevarstvenih dovoljenj je pomembna spodbuda podjetjem, da se odločajo za okoljske naložbe. Posebnih skrbi, prilagajanju zahtevam direktive IPPC slovenskim podjetjem, ne povzroča, saj so se le-ta prisiljena prilagajati evropskemu tržišču, kajti drugače ne bodo konkurenčna, $v$ to pa jih tudi silijo tuja podjetja. Trenutno bo moralo pridobiti okoljevarstveno dovoljenje okoli 190 podjetij, ki se uspešno prilagajajo zahtevam direktive IPPC (Marcon, 2006, str. 2).

Problemi, ki se pojavljajo pri pridobivanju teh dovoljenj, so $v$ velikem številu upravnih postopkov in tudi $\vee$ velikem obsegu dokumentacije, ki jo je treba priložiti vlogi za pridobitev okoljevarstvenega dovoljenja. Okoljevarstveno dovoljenje se zahteva za emisije $v$ zrak, emisije $v$ vode, itd. Če ima podjetje naprave, ki so vir emisij tako $v$ vode kot tudi $v$ zrak, itd. mora pridobiti več okoljevarstvenih dovoljenj, torej je potrebnih več upravnih postopkov. Vloga zahteva tudi pripravo izjemno obsežne dokumentacije. 


\subsection{Okoljske dajatve}

Pri okoljskih dajatvah je treba vsako dejavnost prijaviti pred začetkom opravljanja dejavnosti pri vsaki posamezni okoljski dajatvi. Obrazci, potrebni za prijavo, so sestavni del uredbe, ki ureja posamezno področje. Večina uredb ima štiri priloge. $\vee$ prvi prilogi je predstavljen seznam posameznih asortimentov dejavnosti, $v$ drugi prilogi je obrazec za obračun okoljske dajatve, $v$ tretji prilogi je zahtevek za vračilo okoljske dajatve, kjer je to mogoče, in $v$ četrti prilogi obrazec za prijavo dejavnosti.

Administrativni stroški so lahko veliki, če je podjetje zavezanec po več predpisih. Podjetje, ki je zavezanec za električno in elektronsko opremo, je skoraj zagotovo tudi zavezanec za embalažo, saj je električna in elektronska oprema, ki se daje $v$ promet, vedno tako ali drugače embalirana. Tako je podjetje obremenjeno tako finančno kot administrativno (Marcon, 2006, str. 3).

Natančneje so bili analizirani obrazci za pridobivanje okoljskih dovoljenj na področju odlaganja različnih vrst odpadkov. Za to področje obstaja zares veliko število različnih obrazcev, kar si lahko razlagamo tudi z velikim številom različnih vrst odpadkov. Vendar bi lahko te obrazce poenostavili in nekatere tudi združili. Natančno vsebino obrazcev predpisuje Pravilnik o ravnanju z odpadki in še nekateri področni pravilniki, ki urejajo posamezno vrsto odpadkov. Na področju odlaganja odpadkov gre za različne dejavnosti, kot so na primer sežiganje odpadkov, predelava odpadkov ter zbiranje določenih vrst odpadkov (nevarnih, nenevarnih, itd.). Obrazci za različne dejavnosti na področju odpadkov so si zelo podobni, tako da bi lahko nekatere združili oziroma jih poenostavili, to pa bi olajšalo delo tistim podjetjem, ki zaprosijo za različne dejavnosti na področju odpadkov. Obrazci so večinoma sestavljeni iz treh delov, kjer je potrebno posredovati podatke. $\vee$ prvem delu je treba posredovati splošne, matične podatke podjetja, kot so naziv, sedež, davčna številka, matična številka, šifra dejavnosti, kontaktna oseba, itd. $V$ drugem delu je treba posredovati podatke o napravi oziroma o odpadkih, ki se bodo zbirali, $v$ tretjem delu pa je nanizan seznam dokumentacije oziroma prilog, ki jih je potrebno priložiti prijavi. Najpogostejši so naslednji dokumenti: uporabno dovoljenje, izpis iz sodnega registra, načrt ravnanja z odpadki, poročilo o obratovalnem monitoringu. Pri nekaterih napravah oziroma odpadkih je potrebno seveda posredovati še nekatere druge vrste podatkov, vendar $\checkmark$ povprečju je število teh prilog štiri. Za pridobivanje okoljevarstvenega dovoljenja na področju odpadnih voda in emisij ogljikovega dioksida so ti obrazci bolj obsežni kot pri odpadkih, tudi število prilog, ki jih je treba priložiti, je bistveno večje, saj gre resnično za področje, kjer se najbolj onesnažuje okolje. 


\section{Maja Klun, Luka Petkovšek Analiza administrativnih bremen okoljskih predpisov v Sloveniji}

Za druge dejavnosti, za katere se plačuje okoljska dajatev, je treba dejavnost prijaviti pri Carinski upravi Republike Slovenije, na uradu Jesenice na posebnem obrazcu za vsako dejavnost posebej. Obrazci za prijavo dejavnosti so si za posamezno dejavnost zelo podobni. Sestavljeni so iz treh delov, najprej je treba posredovati splošne podatke o podjetju (firma, sedež, davčna številka, matična številka, itd.) ter vpisati za katero dejavnost se prijavlja. Nato sledijo podatki o vrsti vpisa, kjer je treba označiti, ali gre za priglasitev začetka dejavnosti, spremembo dejavnosti ali prenehanje dejavnosti. $\vee$ zadnjem delu pa je treba navesti, na katere vrste izdelkov se nanaša dejavnost. To pomeni, da je večji del obrazca za različne dejavnosti podoben, kar pomeni, da bi se lahko te obrazce združilo, saj so, kakor smo omenili že zgoraj, nekatera podjetja zavezanec za več dejavnosti hkrati, vendar morajo izpolnjevati in prilagati priloge za vsako dejavnost posebej.

Za druge dejavnosti, kot so odpadna embalaža, izrabljene gume ter električna in elektronska oprema je treba dejavnost samo prijaviti in se evidentirati pri Carinski upravi Republike Slovenije, na uradu Jesenice, razen za področje električne in elektronske opreme, pri čemer se je treba vpisati še $v$ evidenco pri Agenciji RS za okolje. Obrazca za električno in elektronsko opremo za prijavo dejavnosti pri Carinski upravi RS oziroma vpis v evidenco pri Agenciji RS za okolje sta si v splošnem delu podobna (zahtevata podatke kot so naziv, sedež podjetja, itd). Obrazec za vpis $v$ evidenco je $\vee$ nadaljevanju bolj natančen, saj je treba posredovati še natančnejše podatke, kot so npr. načrt ravnanja z odpadno opremo, ter priložiti do štiri priloge, odvisno od vrste načrta ravnanja z odpadno opremo, medtem ko je obrazec za prijavo dejavnosti bolj enostaven, saj se poleg splošnih podatkov vpiše še vrsta vpisa in katere vrste električne in elektronske opreme bo prijavitelj zbiral.

\subsection{Podvajanje registra}

Za vse vrste dejavnosti, povezane z okoljskimi dajatvami, se vodijo evidence, ki jih vodi ali Agencija RS za okolje ali Carinska uprava RS. Agencija RS za okolje vodi evidence za področje izpustov ogljikovih dioksidov, odlaganja odpadkov in odpadne vode. Za področje mazalnih olj in tekočin, izrabljenih motornih vozil, izrabljenih gum, odpadne embalaže ter električne in elektronske opreme skrbi Carinska uprava RS. Na podlagi teh evidenc se tudi obračuna okoljska dajatev, ki se obračunava bodisi mesečno ali trimesečno. Skupno število zavezancev, za katere vodi evidenco Carinska uprava RS, je bilo na dan 25. januar 2007 1877, od tega se jih 1477 (79\%) prijavi za eno dejavnost, 400 (21\%) pa za dve ali več dejavnosti. Po posameznih dejavnostih je število zavezancev 
Maja Klun, Luka Petkovšek

Analiza administrativnih bremen okoljskih predpisov v Sloveniji

naslednje: za področje mazalnih olj in tekočin 179 zavezancev, izrabljenih motornih vozil 333 zavezancev, izrabljenih gum 121 zavezancev, odpadne embalaže 1063 zavezancev ter električno in elektronsko opremo 635 zavezancev. Tako je največ zavezancev za področje odpadne embalaže ter električne in elektronske opreme. Ti dve področji sta si zelo sorodni, tako da so številni zavezanci hkrati zavezanci za obe vrsti dejavnosti. Agencija RS za okolje pa je zadolžena za 1480 zavezancev, od katerih jih 1405 zaprosi za eno dovoljenje, 75 pa za dve ali več dovoljenj. Agencija RS za okolje ima tako za področje onesnaževanja zraka z emisijo ogljikovega dioksida 148 zavezancev, odlaganja odpadkov 642 zavezancev, od katerih jih 513 zaprosi za eno dovoljenje, 129 pa za dve ali več dovoljenj. Za odpadne vode je skupno 752 zavezancev (od tega je zavezancev za industrijske naprave 673, za čistilne naprave pa 95), od katerih jih 737 zaprosi za eno dovoljenje, 15 pa za dve ali več dovoljenj.

Primerjava registrov Agencije RS za okolje in Carinske uprave RS skupaj kaže, da se podjetja podvajajo tudi $\vee$ tem primeru, kar pomeni, da so hkrati zabeležena $\vee$ obeh evidencah. Ta odstotek sicer ni zelo visok. Gre za 3\% podjetij, kar pomeni, da se 89 podjetij pojavi v obeh evidencah.

Da vsa ta podvajanja vplivajo moteče, je pokazala tudi anketa med zavezanci in pridobitelji dovoljenj, saj največ podjetij meni, da se stroški povečujejo zaradi povečevanja kompleksnosti obstoječih predpisov. To meni kar 53\% podjetij. 41 \% podjetji pa meni, da je razlog za višje stroške uvedba novih predpisov s tega področja (Ciljno raziskovalni projekt, 2007).

\subsection{Frekvenca obračunskih obdobij}

Analiza pobranih prihodkov posamezne okoljske dajatve, število zavezancev in število letnih obračunov pokažejo, da so pri nekaterih dajatvah povprečno vplačana sredstva na obračun na zavezanca zelo nizka in z vidika zavezanca neekonomična. Pri tem je treba upoštevati tudi dejstvo, da podatki o prilivih vsebujejo le bruto prilive, torej brez upoštevanih vračil, ki so možna pri nekaterih dajatvah. Naslednja slabost oddajanja obračunov okoljskih dajatev je tudi $v$ tem, da zavezanci oddajajo obračune tudi v primeru, ko je njihova obveznost enaka nič.

Pri preliminarnih rezultatih raziskave, ki se izvaja na Fakulteti za upravo, so bili povprečni stroški zavezanca, povezani z izpolnjevanjem okoljskih predpisov, ocenjeni na 1.378 evrov. Hipotetično to pomeni, da če je povprečni zavezanec dolžan obračunati samo eno dajatev na leto in je frekvenca obračuna 12 (torej 
vsak mesec), potem je povprečni strošek obračuna ocenjen na dobrih 114 evrov, kar je več kot pobrani znesek dajatve v primeru odlaganja odpadkov.

Tabela 1: Analiza obračunov okoljskih dajatev

\begin{tabular}{|c|c|c|c|c|c|}
\hline dajatev & $\begin{array}{l}\text { skupni } \\
\text { prihodki v } \\
\text { EUR }\end{array}$ & $\begin{array}{c}\text { število } \\
\text { zavezancev }\end{array}$ & obračun & $\begin{array}{l}\text { dajatev na } \\
\text { obračun v } \\
\text { EUR }\end{array}$ & $\begin{array}{l}\text { povprečno } \\
\text { vplačana } \\
\text { dajatev na } \\
\text { zavezanca na } \\
\text { obračun v } \\
\text { EUR } \\
\end{array}$ \\
\hline $\begin{array}{l}\text { Emisije ogljikovega } \\
\text { dioksida }\end{array}$ & 33.585 .812 & 166 & 12 & 2.798 .818 & 16.860 \\
\hline Mazalna olja in tekočine & 2.439 .989 & 179 & 12 & 203.332 & 1.136 \\
\hline $\begin{array}{l}\text { Izrabljena motorna } \\
\text { vozila }\end{array}$ & 6.024 .215 & 333 & 12 & 502.018 & 1.508 \\
\hline Odlaganje odpadkov & 828.981 & 642 & 12 & 69.082 & 108 \\
\hline Odpadne vode & 5.928 .050 & 752 & 12 & 494.004 & 657 \\
\hline Izrabljene gume & 1.198 .736 & 121 & 4 & 299.684 & 2.477 \\
\hline Odpadna embalaže & 548.335 & 1.063 & 4 & 137.084 & 129 \\
\hline $\begin{array}{l}\text { Električna in } \\
\text { elektronska oprema }\end{array}$ & 164.860 & 635 & 4 & 41.215 & 65 \\
\hline SKUPAJ & 50.718 .974 & 3.891 & I & I & I \\
\hline
\end{tabular}

Vir: MF 2007b

\section{Zaključek}

Analiza administrativnih bremen na področju okoljskih predpisov v Sloveniji je pokazala, da le-ta prevečkrat vodi $v$ podvajanje aktivnosti in poročanja podjetjem, ki morajo pridobivati okoljska dovoljenja oziroma vplačujejo okoljske dajatve. Prav tako se je pokazalo, da je pogostost obračunov pri nekaterih dajatvah neekonomična za zavezance. $V$ drugih državah so prišli do podobnih ugotovitev in spremenili obstoječo zakonodajo tako, da so postopki poenostavljeni, prav tako pa so znižali število obračunov na leto pri okoljskih dajatvah. Podobni ukrepi bi v Sloveniji bistveno pripomogli k znižanju administrativnih stroškov in bremen za podjetja, ki se soočajo z analizirano problematiko. 
Maja Klun, Luka Petkovšek

Analiza administrativnih bremen okoljskih predpisov v Sloveniji

Doc. dr. Maja Klun je julija 2002 uspešno zagovarjala doktorsko disertacijo in tako pridobila naziv doktorja znanosti s področja ekonomije, leta 2005 pa je bila prvič izvoljena $v$ docentko za področje ekonomike javnega sektorja. Njena poglavitna raziskovanja so s področja davkov, ciljno usmerjenega proračuna in merjenja uspešnosti in učinkovitosti $v$ javnem sektorju.

Luka Petkovšek je po končanem dodiplomskem visokošolskem strokovnem študiju na Fakulteti za upravo nadaljeval specialistični študij Javne uprave in v juniju 2007 pod mentorstvom doc. dr. Maje Klun z oceno odlično zagovarjal specialistično delo na temo Ovrednotenje administrativnih ovir na področju okoljskih predpisov. 


\section{Analiza administrativnih bremen okoljskih predpisov v Sloveniji}

\section{Literatura in viri}

- $\quad$ ARSO, (2007): IPPC - Celovito preprečevanje in nadzor onesnaževanja. Agencija RS za okolje. http://okolje.arso.gov.si/ippc/. 30.02.2007.

- $\quad$ CURS, (2007): Okoljske dajatve. Carinska uprava RS. http://www.carina.gov.si/si/informacije_za_ciljne_skupine/informacije_za_podjet ja/. 15. 02. 2007

- DEFRA. (2006a): Environmental Permitting Programme, Department for Environment Food and Rural Affairs, London.

- DEFRA. (2006b): The Defra Simplification Plan: Maximising Outcomes, Minimising Burdens, Department for Environment Food and Rural Affairs, London.

- Filiplič, J. (2004): Okoljska regulacija in konkurenčnost države, Ekonomska fakulteta, Ljubljana.

- $\quad$ FOCUS, (2007) Podnebne spremembe, Focus društvo za sonaraven razvoj http://www.focus.si/index.php?node=15 25.01.2007.

- Klun, M. (2006): Davčni sistem, Fakulteta za upravo, Ljubljana.

- Marcon, P. (2006): Industrijo bremenijo emisijski kuponi in IPPC, Finance Priloga Okolje \& Energija, št. 227, str. 2-3.

- Mešl, B. (2004): Finančni učinki soočanja podjetij z zahtevami varstva okolja, Ekonomsko-poslovna fakulteta, Maribor, 2004.

- $\quad$ MF, (2007), Bilten javnih financ. Ministrstvo za finance, let. 9, št. 2 str. 30.

- OECD, (2003). From Red Tape to Smart Tape. Organisation for Economic Cooperation and Development, France.

- Praška izjava, (2005).

- $\quad$ SCM NETWORK, (2007): Simplification Catalouge / Environment. SCM Network.

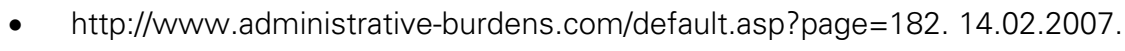

- Uredba o vrsti dejavnosti in naprav, ki lahko povzročajo onesnaževanje okolja večjega obsega. Ur. list RS, št. 97/2004.

-Zakon o varstvu okolja. Ur. list RS, št. 41/2004, 20/2006. 
Maja Klun, Luka Petkovšek

Analiza administrativnih bremen okoljskih predpisov v Sloveniji

SUMMARY

\section{ANALISYS OF ADMINISTRATIVE COSTS OF ENVIRONMENTAL REGULATIONS IN SLOVENIA}

Administrative costs and related administrative barriers are an increasingly important factor. Administrative costs connected with meeting environmental regulations become problematic when they include a high level of administrative burdens. "Administrative costs" denotes all the costs that companies incur in meeting requirements stemming from various regulations; these include reports, various documentation, forecasts, and so on. Another part of these costs is meeting demands to provide information that companies would not prepare if not required to do so by various regulations. This portion of the costs is called the "administrative burden." The basic act in the Republic of Slovenia concerning environmental protection is the Environmental Protection Act, which sets forth all the fundamental environmental protection principles, environmental protection measures, environmental condition monitoring and information about environment, economic and financial instruments of environmental protection, environmental protection public services, and other issues related to environmental protection. In addition, the European Union plays an important role by promoting environmental protection at the international level because the natural environment has no boundaries. The EU will continue to play a key role in promoting multinational and multilateral agreements; here, the Kyoto Protocol is worthy of mention.

The economic and financial instruments through which countries promote and encourage the achievement of environmental protection goals are important for reducing administrative burdens. These instruments include environmental taxes, insurance, bank guarantees and other forms of financial guarantees, loans with better interest rates for investments that contribute to environmental protection, deposits and other forms of savings, emissions trading, joint investments in projects that decrease environmental pressures, and budget funds. In Slovenia, there are currently eight environmental taxes in force: taxes on air pollution caused by $\mathrm{CO} 2$ emissions, and taxes on environmental pollution caused by the use of lubricating oils and liquids, end-of-life vehicles, waste disposal, waste water discharge, used tires, packaging waste, and waste electrical and electronic equipment. The majority of state budget inflows come from the tax on air pollution caused by $\mathrm{CO} 2$ emissions because the 
largest polluters are subject to this tax. The smallest amount of inflows comes from the three new environmental taxes introduced in 2006. Environmental taxes represent a relatively small part of the state budget; in 2006 they accounted for only $0.7 \%$ of overall revenues and, in 2005 , for $0.9 \%$.

Today companies place too much focus on the time spent and costs incurred in regulatory procedures; on the other hand, they also tend to underestimate the benefits of these regulations for the economy and society as a whole. This leads to the opinion that environmental regulations burden the economy, cause inefficiency, and weaken competitiveness. According to some economists, in addition to increased production costs, another drawback that becomes clear in practice is the fact that environmental regulations cause "dirty" industries to move to countries with less demanding environmental requirements. However, it must be emphasized that research findings demonstrate that environmental regulations do not have a negative effect on company and state competitiveness if appropriate environmental measures are taken that encourage company productivity and if these are effectively implemented.

Upon admission to the European Union, Slovenia started accelerating operations in public administration effectiveness, introducing certain principles that once only applied to the commercial sector into the state, or public, administration as well. This is primarily the realm of the Ministry of Public Administration. An important step forward in creating a friendly and effective public administration and eliminating administrative barriers is represented by the Program of Measures for Eliminating Administrative Barriers, which the government adopted at the end of 2005 at the proposal of the Ministry of Public Administration.

The greatest burden concerning environmental regulations is the acquisition of various permits, because all the operators that perform an activity or own an appliance that can cause large-scale environmental pollution must obtain an environmental protection permit. Acquiring these permits provides an important impetus for companies to make environmental investments. The problems arising from the acquisition of these permits result from the large number of administrative procedures, as well as the extensive documentation that must be enclosed with the application to obtain the permit. In addition, barriers occur with environmental taxes because every activity must be registered for each individual environmental tax before it is implemented. The administrative costs can 
Maja Klun, Luka Petkovšek

Analiza administrativnih bremen okoljskih predpisov v Sloveniji

be substantial if a company is taxable under several regulations. For example, a company that is subject to the electrical and electronic equipment tax is bound to be subject to the packaging waste tax as well, because electrical and electronic equipment that is placed on the market is always packaged in some way. The company is therefore burdened both financially and administratively.

Records for all types of activities subject to environmental taxes are kept either by the Environmental Agency or the Customs Administration. On the basis of these records, the environmental tax is calculated on a monthly or quarterly basis. On 25 January 2007, the total number of taxable entities on whom the Customs Administration keeps records was 1,877 , among whom 1,477 (or $79 \%$ ) were registered for one activity, and $400(21 \%)$ for two or more activities. The number of taxable entities by individual activities is as follows: 179 for lubricating oils and liquids, 333 for end-of-life vehicles, 121 for used tires, 1,063 for waste packaging, and 635 for electrical and electronic equipment. A comparison of registers kept by the Environmental Agency and Customs Administration shows that companies are duplicated, which means they are recorded in both registers at the same time. An analysis of revenues collected for individual environmental taxes, the number of taxable entities, and the number of annual assessments shows that with certain taxes the average amounts paid per taxable entity per assessment are very low and uneconomical from the taxable entity's viewpoint. However, it must be taken into account that the information on inflows only includes gross amounts without taking into account the refunds that are possible with certain taxes. A further drawback of submitting environmental tax assessments is that taxable entities must submit them even if they owe no tax. 